\title{
Subverting Justice: Socio-Legal Determinants of Impunity for Violence against Women in Guatemala
}

\author{
Cecilia Menjívar ${ }^{1, *}$ and Shannon Drysdale Walsh ${ }^{2}$ \\ 1 Department of Sociology, University of Kansas, Lawrence, KS 66045, USA \\ 2 Department of Political Science, University of Minnesota Duluth, Duluth, MN 55812, USA; \\ shannondwalsh@gmail.com \\ * Correspondence: menjivar@ku.edu; Tel.: +1-785-864-4111 \\ Academic Editor: Jill C. Engle \\ Received: 31 May 2016; Accepted: 4 July 2016; Published: 11 July 2016
}

\begin{abstract}
High levels of violence against women and impunity in Guatemala have reached crisis proportions and have received increased international attention in recent years. The phenomenon of feminicide (e.g., killings of women in the context of state impunity), is widespread in Latin America and particularly acute in Guatemala. Many (if not the majority) are rooted in violence that becomes concentrated in the family. In this paper, we propose that both the structure and application of the laws in Guatemala contribute to widespread impunity. Police and judges use laws other than those created to address violence against women in order to justify lack of enforcement. For example, judges resist issuing restraining orders, and police refuse to apply them because this can violate perpetrators' property rights. Judges also refuse to apply domestic violence laws because this violates the principle of equality under the law. Women refuse to use the legal system to seek justice because alimony laws will not be enforced and women are economically dependent. The discriminatory fashion in which these laws are applied leads to widespread impunity. Even though laws on the books could be applied otherwise, those who implement them privilege laws that conflict with violence against women laws. While much scholarship focuses on individual-level motives for violence, we instead analyze the socio-legal environment and existing legal codes that enable continued failure to respond adequately to violence against women. The legal framework and the legal code itself are deeply shaped by the context in which they are written - the structural, gender, symbolic, everyday and long arm of political violence that permeate all aspects of life in Guatemala and exacerbate women's vulnerability, especially the poor. We argue that this broader legal context endangers the lives of women in Guatemala. We also extend the socio-legal scholarship to highlight failures for victim's families and the disempowerment of women as they enter relationships.
\end{abstract}

Keywords: violence against women; impunity; feminicide; femicide; Guatemala; violence in Central America; discriminatory laws

"In some cases, where judges value property rights over the safety of women, judges have refused to order men removed from their homes because they consider it unconstitutional." ([1], p. 8)

\section{Introduction}

As the quote above illustrates, legal procedures meant to protect women from violence, such as protection orders, fail to be implemented. Justice system officials even rationalize doing so in the name of the law itself. Thus, police and judges often use laws other than violence against women laws (VAW laws) to justify lack of enforcement. As in the above example, judges or police often refuse to remove a perpetrator from a house because doing so could violate his property rights, since men often 
own the homes in which they live with their wives or partners. Judges refuse to apply laws designed to protect women from violence because this could violate the principle of equality under the law. The judges' rationale is that the law would give preferential treatment to women because there are no analogous laws to protect men against violence. Indeed, women often refuse to use the legal system to address gender violence against them because alimony laws are not enforced and women are often economically dependent on their male partners. Accordingly, given the gender discriminatory way that these other laws, which govern marriage, divorce, alimony, property rights, etc., are written and applied, they systematically place women at a disadvantage in various key aspects of life. Far from protecting them, this legal culture endangers women's lives.

Guatemalan society is a social context of "multisided violence", in which multiple forms of violence, such as structural, political, everyday, symbolic and gender violence, exist in tandem [2]. Often violence against women, inscribed in everyday practices, intimate relations and institutions, is perceived by the state and society as unremarkable, as the "way things are" or, often, as the fault of victims. The various forms of violence that Guatemalan women endure in their daily lives are deeply connected to one another and to broader structures and institutions in Guatemalan society [2]. Laws are interpreted through the lens of this social context that normalizes violence against women. A natural outcome is to uphold existing laws that reinscribe women's subordination in a way that conflicts with laws that are meant to protect women's physical integrity rights. Gender inequalities in access to health, education, well-paying jobs, reproductive rights, to name a few, are not independent of these other forms of suffering women face routinely, as well as of the more egregious forms of violence, such as their killings [2]. Between 2000 and 2011, there were between 200 and more than 700 murdered women per year in Guatemala. However, this is the tip of the iceberg, as many crimes against women go unreported. If women do report them, quite often, they are not investigated [3].

In this article, we propose that the gender discriminatory social context, as well as the discriminatory structure and the application of laws in Guatemala contribute to widespread impunity. This broader socio-legal framework constitutes the backdrop within which laws designed to address violence against women are supposed to be implemented. However, the latter laws are likely to be ineffective and futile because the socio-legal context that generally discriminates against women is left unchanged even when laws meant to protect women are passed. Consequently, laws meant to address violence against women become difficult to implement or are often simply ignored in favor of implementing laws that maintain the status quo of gender inequality. This legal context, composed of a wide range of laws (beyond laws to protect women from violence), together with the broader social context that normalizes violence in the lives of women, provides little disincentive for gender-based violence against women and results in high levels of impunity in crimes against them.

Furthermore, even though these other laws on the books could be applied more in line with their intent, officials in charge of interpreting and implementing them prioritize the laws that sustain gender inequalities, rather than laws that address violence against women. This is the case when laws are written and implemented in a context of profound gender, class and ethnic inequalities. This environment disadvantages all women, but in particular women who are poor and already vulnerable endure justice subverted. Thus, while much scholarship focuses on individual-level motives for crime against women (see [4]), we analyze the socio-legal environment that enables continued failure to respond adequately to violence against women in Guatemala. Often, "aspects of social reality" affect how laws are implemented. As Godoy-Paiz ([5], p. 39) insightfully observes for the case of Guatemala, "A strictly legal, formal rights-based, framework such as the one ascribed to by the Guatemalan [S]tate, treats violence as an act involving an individual perpetrator and victim. This approach is problematic as it ignores the social conditions that give rise and sustain relations of domination."

In going beyond individual-level treatments of gender violence against women, we focus on two interrelated components of the context within which laws intended to protect women fail them: the social milieu and the broader legal context within which laws are enacted. First, we place our 
examination within the broader context in which the women, the people who commit violent acts against them, those who write laws and those who implement them live. We underscore that they all live in the same social context, so that their attitudes and understandings of violence (especially of violence in the lives of women) are all shaped, in various ways, by the system of inequalities they experience daily. A contribution of our examination is that we also go beyond the social context alone to demonstrate how this context is reflected, informed by, embedded in and perpetuated by the broader legal context. Thus, we also examine laws that impinge in one way or another on the lives of women and that inform how laws designed to address violence against women are interpreted and implemented. Just as laws are not written and interpreted in a social vacuum, they are not interpreted and implemented in a legal vacuum either. This relationship, between laws to address violence against women and laws that govern family matters, marriage and divorce, is fundamental to our examination. This socio-legal approach permits us to analyze the efficacy of laws to address violence against women in Guatemala. Violence against women (VAW) laws are one component of a broader legal context. Therefore, while new laws to address gender violence against women signal a good direction, having "lagging" laws in other spheres of life, which are still anti-woman, slows down the potential of these new laws for social change. It makes it difficult for justice system practitioners to apply new, progressive laws when they have decades of experience applying discriminatory ones in other spheres of life.

We begin by delineating the broader social context to highlight the gender discriminatory treatment that women, particularly the poor and vulnerable, experience in most aspects of life in Guatemala. We then examine the civil code and the various discriminatory laws that bias women in family matters, which have been invoked by justice system practitioners and local law enforcement officers when dealing with cases of violence against women. Next, we focus more specifically on the various laws addressing violence in the lives of women that Guatemala has passed within the past two decades, as well as the institutions that have been reformed to address violence against women. This approach allows us to point to how legal structures more broadly endanger the lives of women in Guatemala. To accomplish our goals, we draw on sworn affidavits from experts in Guatemala which reveal how this socio-legal context reproduces discrimination, as well as on reports and government statistics. We end with a discussion of how these different layers are embedded to render the legal system ineffective, impunity levels high and justice for women subverted. In the next section, we provide a brief summary of conditions for women in Guatemala (see Figure 1 for a visual reference of how the lack of the implementation of laws on violence against women is embedded in a broader discriminatory socio-legal context).

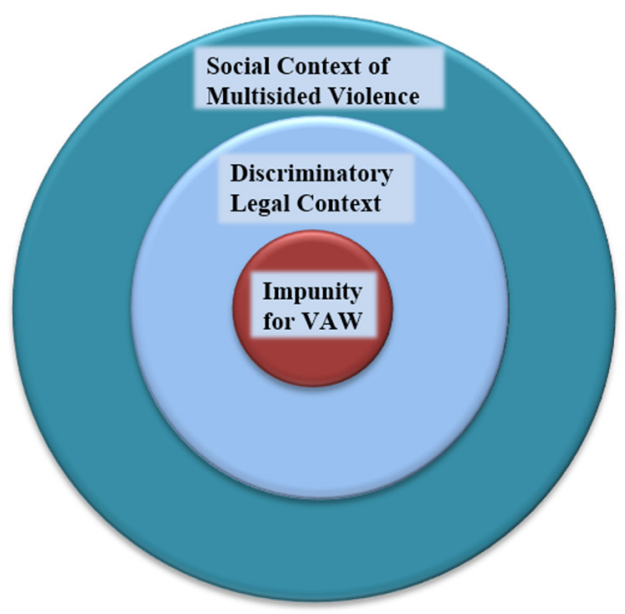

Figure 1. The socio-legal context of impunity for violence against women (VAW) laws. 


\section{Country Background}

In Guatemala, citizens often plan their daily routines around attempts to avoid becoming victims of violent crime. Everyday violence is widespread, and poor women have the highest risk of exposure and the fewest means to avoid it. According to the UN Office on Drugs and Crime (UNODC) report on homicides in 2012, Guatemala's rate was 39.9 homicides per 100,000, nearly converging with El Salvador, which generally has higher homicide rates than Guatemala. ${ }^{1}$ By contrast, rates for the United States and Canada were 4.8 and 1.6, respectively. See Figure 2 for comparative homicide rates from 2000-2012.

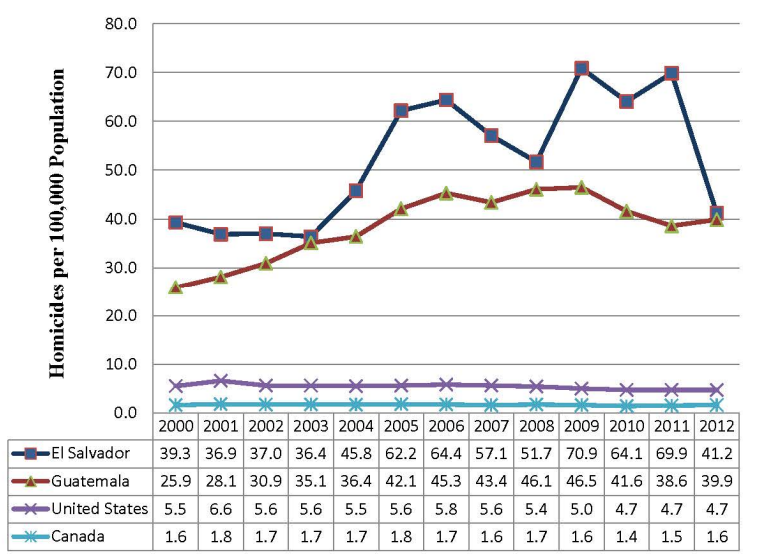

Figure 2. Homicide rates in El Salvador and Guatemala vs. North America.

Homicide rates reveal overall patterns of murder, but they do not reveal the particular types of victimization that women disproportionately face, including domestic abuse and sexual violence. Thus, Guatemalan women live in a context of generalized violence and insecurity, as well as violence that is directly targeted against them [6]. High rates of domestic violence in many instances have led to feminicide, but even in the most egregious cases, these are seldom prosecuted [3]. As Figure 3 demonstrates, Guatemala has generally had the highest rate of killings of women in Central America from 2002-2011.

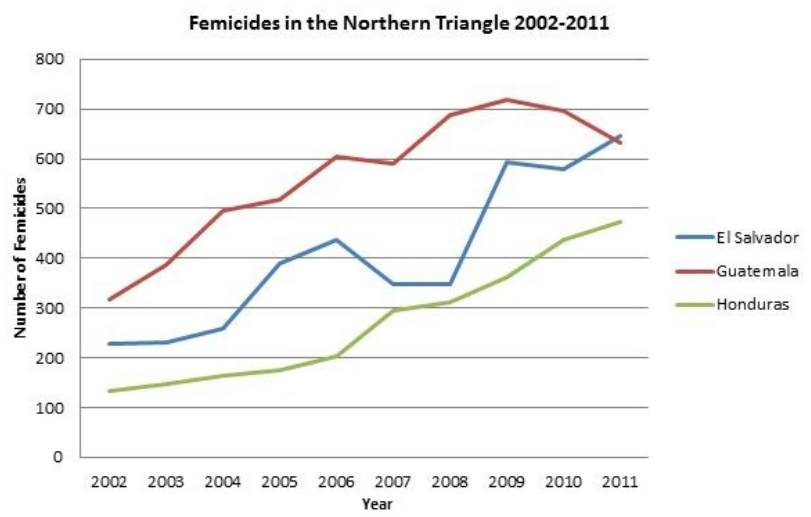

Figure 3. Femicides in the Northern Triangle 2002-2011. ${ }^{2}$ Sources: National Comission of Human Rights (CONADEH, Honduras) National Civilian Police (PNC, Guatemala), Institute of Legal Medicine (Instituto de Medicina Legal, El Salvador).

1 UNODC Data. United Nations Office on Drugs and Crime. These are rates reported at the country level, usually through the National Police, and are more conservative than other estimates.

2 Figure by Edward Fox [7]. 
The U.S. Department of State reported the 2012 conviction rates in Guatemala for domestic or intrafamilial violence at a mere $2 \%$ (with 18,194 cases and 376 convictions). ${ }^{3}$ Although we do not explore the effects of women's different social markers on experiences of violence in depth in this article, we would like to mention that key social cleavages intersect to create heterogeneity in their experiences of violence (see [8]). For instance, a critical social position in Guatemala is ethnicity, which exacerbates the situation for women, since the indigenous Maya, who make up more than half of the country's population, have been found at a disadvantage in every social indicator. During the second half of the three-decade-long civil conflict in Guatemala (between 1960 and 1996), indigenous Maya became the target of scorched-earth campaigns and brutal violations [9], amounting to genocide in several cases. Mayan women are disproportionately rural, poor, discriminated against and lack support from the police, as well as access to justice system institutions [10]. Furthermore, when indigenous Maya women seek justice for the violence they endure, they are the least likely to be heard.

\section{Multisided Violence: The Broader Social Context}

The broader social context in Guatemala contains multiple forms of violence that converge to institutionalize discrimination against women in everyday practices and in the application of laws. Some forms of violence in the lives of Guatemalan women are not visible or recognizable as violence because they harm in non-physical, but impactful ways. They also influence how the justice system contributes to normalizing violence in the lives of women and how officials in this system subsequently interpret the laws in ways that often reinscribe the normalization of this violence. We use the lens of "multisided violence", developed for Guatemala [2], to highlight these various sources of suffering and less visible forms of violence in order to set the legal system-the civil code and the laws that have been passed to address violence in the lives of women-in context. This broader context is key in understanding why the civil code still retains laws that are harmful to women and how laws specifically aimed to address gender-based violence against women are ineffective. Here, we briefly describe the various facets of multisided violence that permeate Guatemalan social structures in the forms of structural, political, everyday, symbolic and gender violence.

Structural violence refers to persistent conditions of inequality created by larger forces, such as markets, corporations and global processes that disadvantage poor countries. It is created by the insecurity of wages, chronic deficit in basic goods and services [11] and reproduced in the context of the market and in exploitative labor relations [12]. In Guatemala, these conditions are created by a sweatshop economy, as well as an agricultural and land tenure system that disadvantages the poor and exacerbates gender vulnerabilities [2]. These conditions are rooted in a profoundly unequal class system that has left most of Guatemala's population (indigenous and non-indigenous alike) poor and without access to services- - health, education, etc.- to fulfill basic needs. It is not poverty alone, however, that delimits and constrains people's lives, but the structures that produce such inequalities and create conditions for the socially vulnerable to bear the effects of these powerful inequalities. As Bourgois [13] notes, the broader political economy does not cause violence directly, but one must understand the extent to which it conditions structures within which people suffer and end up inflicting harm on one another and distort social relations.

Political violence, in which state-sponsored terror figured centrally, extended its reach to most of the population in Guatemala during the three-decade civil war. This violence came in the form of disappearances, massacres, assassinations and strategic placement of gruesome killings in public spaces, all of it broadcast daily in the media. However, one of its most insidious aspects was the government's reliance on civilians to kill civilians [14], which contributed to the normalization of violence in interpersonal relations, but also deeply affected the constitution of the self, people's cognitive frames and, as such, profoundly transformed social relations [2]. The political violence

3 The Department of State cited these data from the Public Ministry in Guatemala. 
that claimed thousands of lives in the highlands was so pervasive that it engulfed the entire country, emerging in different forms in other regions [2]. Political violence thus contributed to a "militarization of the mind", normalizing the use of force and submission to power in everyday life [15], with important repercussions to the present, as the sexual violence and other forms of torture used against women during the civil war years persist today [16]. UN Rapporteur Yakin Erturk also noted that, "The problems of socio-economic inequality and exclusion that sparked the civil war remain unresolved, leaving women, particularly those of indigenous descent, at risk of violence due to the compounded discrimination they face based on sex, ethnicity, and class" ([17], p. 2). Accountability for wartime abuses against women is an exception in Guatemala, as exemplified by the recent prosecution of military personnel committing sexual slavery in the Sepur Zarco case over three decades after the fact [18]. Importantly, the political violence of the past has a long arm, as the violence from "common crime" today is intricately related to historical legacies more generally, but also directly, as former military officers have emerged as government officials today, in charge of designing and defining legal practices and structures. ${ }^{4}$

Everyday violence is expressed as routine interpersonal violence at the micro level, including aggression, crimes, domestic violence and psychological terrors that people, especially women, often experience in the context of intimate spaces like the home or the neighborhood. It is usually referred to as "common crime", because it occurs frequently and everywhere to the point that its ubiquity can make it fade from view. The civil war and subsequent social violence in Guatemala exemplify everyday violence as the "individual lived experience that normalizes petty brutalities and terror at the community level and creates a common sense or ethos of violence" ([13], p. 426). Noteworthy, even though everyone in the country is exposed to these expressions of violence, social position intersects with its effects [8] to create heterogeneous experiences of violence. For the most vulnerable and marginalized groups their multiple disadvantages amplify such effects. Additionally, in general, this routinization of violence can lead everyone touched by it to accept it as part of the way things are.

Symbolic violence, according to Bourdieu [19], refers to the internalization of inequalities, humiliations and hierarchies that range from racism to sexism to expressions of class power and is often expressed as self-recrimination for one's own suffering, mistreatment and exclusion. From this viewpoint, violence becomes so normalized that it is rendered invisible so that injurious acts, particularly in the lives of women, may not be recognized as such. These acts are rooted in profound gendered inequalities that permeate everyday lives, institutions and state agencies. This omnipresence normalizes violence, and individuals come to understand it through a frame of "the way things are". For women, symbolic violence comes in the form of everyday practices, such as "robadas" (women being "taken" or "stolen") as part of courtship; extreme control over their bodies, social relations and physical movement; a social premium on their honor and "good behavior"; the expectation that they will be partnered and be mothers; and the devaluation of their suffering and their lives more generally [2]. These practices may not on the surface be classified as acts of violence and may indeed be interpreted as "cultural practices". However, they lead to injurious effects and to social suffering for the women whose lives are dictated by these practices. Later, we will see how these various expressions of symbolic violence for women surface in the legal structures that govern marriage, divorce and family life in general.

Importantly, Auyero [20] observes, being exposed to violence everyday does not mean that people will become habituated or desensitized; rather, they become so familiar with it that they simply learn to accept violence as the way things are, such as "we are used to it". The inability and indifference of police and judges to recognize the violence committed against women is an expression of symbolic violence. Symbolic violence therefore intersects with broader structures to reinscribe and institutionalize violence because those who interpret the law, those who suffer from violence

4 We thank one of our anonymous reviewers for bringing this point to our attention. 
and those who commit these acts are all living in the same social milieu where people are "used to it". Thus, women who experience violence in a milieu where structural and political violence make individual-level violence seem habitual and routine are likely to blame themselves for it. In this context, it would be unsurprising that those in charge of interpreting and implementing laws to protect women also blame them for their mistreatment.

Gender violence refers to gender imbalances in the broader structures that disadvantage women; gendered violence comprises the various acts of violence perpetrated against women, consciously or unconsciously, as a mechanism of control, which is often perceived as a normal way of keeping women "in line" [21]. These acts, including physical, psychological and linguistic violence, are committed in a context of gender inequality and serve to sustain this inequality through force and explicit or implicit threats. Expressions of gender violence are found in domestic spaces, public arenas and institutions. A Guatemalan team of social scientists noted that public violence cannot be examined in isolation from domestic violence [22]. In part, they defined violence as the "intentional maltreatment of physical, sexual, or emotional nature, which lead to an environment of fear, miscommunication and silence" ([22], p. 22). They argued that all forms of violence are products of unequal power relations and observed that the greatest expressions of violence are between men and women [22]. Additionally, these are widespread in Guatemala. For example, the 2012 UNDP (United Nations Development Programme) Gender Inequality Index in Guatemala is 0.539 (ranked 133 out of 187 countries). By comparison, the United States is 0.256 and ranked 42 [23]. Gender disparities in Guatemala mean that women have disproportionately less access to land, education and salaried employment (e.g., [24]).

Women in more vulnerable positions on account of ethnicity or class often experience more amplified forms of violence in most aspects of life. Furthermore, the laws intended to criminalize such violence are translated through this same social frame, which re-instantiates its normalization. In the next section, we provide details of the broader discriminatory legal context that reflects and reinforces the profound gender inequality embedded in the social context of multisided violence that we summarized in this section.

\section{Legal Context: The Civil Code and Discrimination against Women in Guatemala}

Within the social context depicted above, it may not be surprising that laws dealing with key aspects of family life-marriage, divorce, employment, property rights-reflect the gender inequalities of the larger society and, in this way, reproduce the structural, political, symbolic and gender violence that persists in Guatemala. These laws are connected to the set of laws that Guatemala passed to address violence against women in several ways. First, within the legal system, these other laws, which we call "adjacent laws", work in conjunction and exert their effect with laws aimed at addressing violence in the lives of women. In a social context that devalues women and that also shapes how laws are written and implemented, it is instructive to examine how specific laws created to address violence against women are related to adjacent laws and work within the overall legal context. Thus, officers and judges often resort to these adjacent laws as they evaluate cases of violence against women, rather than simply apply the VAW laws alone.

Many women who seek justice also know this, as sometimes they avoid filing complaints because they know that laws that often work against them in other realms are in effect and will be used in evaluating their cases. Placing the recent specific VAW laws in this legal context allows us to see how progressive laws embedded in a conservative or discriminatory overall legal code can yield harmful contradictions, pushing women to report violence against them when there is no real legal or institutional structure for them to be able to collect alimony or obtain protection even if they have a restraining order. In the absence of change in the legal code to correct biases against women, progressive laws, such as those to address violence against them, will have little chance to make a difference. As we will discuss later, the 2008 Femicide Law is the most progressive law on violence against women in Guatemala, even more so than the 1996 Intrafamilial Violence Law that preceded it. 
However, VAW laws are embedded in discriminatory laws, and tensions emerge when newer, more progressive laws are applied in the context of persistent discriminatory legal practices.

In this section, we will not cover the entirety of laws in the Guatemalan civil code that work against women; we will only highlight certain pieces of legislation, especially related to the context of the family, that have direct relevance to how VAW laws are interpreted and implemented or that exemplify how women are disadvantaged in unions, divorce, alimony, etc. We provide several examples of how the structure of these laws and their application interfere with the implementation of laws meant to protect women from violence and how such laws and their application reflect the multisided violent context of Guatemalan society. Thus, the laws we discuss represent a narrow sampling of the legal code that governs the lives of and relations between women and men in Guatemala today.

\subsection{The Family and Married Women's Employment Laws}

The Guatemalan civil code [25], in 363 articles between 78 and 441, enshrines the family unit as the basis of society and describes its interests as distinct and separate from those of its individual members. It conceives of the family as an institution based on the principle of unity. The law therefore recognizes a 'family interest' that reflects the definition of the family as a unit, which rests above the interests of its individual members. The seeming neutrality in the law hides the gender inequalities that it preserves and makes possible, further normalizing and formalizing the symbolic violence of such inequalities. When examining the place of the family in adjacent laws that are part of the Guatemalan legal code, gender disparities that disfavor women readily come to light. For instance, women and men or the young and old, among other social asymmetries, do not enjoy the same rights or have the same power in the family. Therefore, treating the family as a 'neutral' unit whose interests rest above those of its individual members undermines the rights of those family members who are socially disadvantaged, such as women.

A few articles codify gender differences and inequalities in the home, reflecting society's views of gendered social roles in the home, giving men authority and power and naturalizing various forms of violence. For instance, Article 111 determines that the husband must protect and help his wife and is obligated to provide her with everything necessary to sustain the household, based on his presumed stronger economic capability. This article establishes that men will be the breadwinners and that women will be in charge of the household, thus naturalizing this gender disparity and creating juridical archetypes for socially expected and accepted gender roles within the family. Article $110^{5}$ addresses a woman's obligations within a marriage. It complements Article 111 by noting that when the man is physically incapable of earning a living, the woman could then step in to cover the household expenses with her salary. Article 134 observes that if the man in the union is under 18 years of age, his legal guardian will assist him in the administration of the home and his property; his wife would only be in charge of household decisions if she is an adult and only until her husband reaches adulthood. Until recently, Article 114 established that the husband could oppose his wife working outside the home if he deemed that her doing so would jeopardize the household's well-being. This article was repealed in December 1998.

\subsection{Marriage and Divorce Laws}

When women marry in Guatemala, the law (Article 108) extends them the right to add their husband's last name to their own, but it is usually done by adding the article "de" (of) before the husband's last name, implicitly designating married women as property "of" their husbands. If the marriage ends, a divorced woman can no longer use her former husbands' last name. There are no parallel laws for men. While these laws do not have direct material consequences based on gender

5 The second paragraph of Article 110 was amended to include that both people in a union have the obligation to care for the children until the children reach adulthood. 
disparities, they contribute to formalize social practices that equate women with property. They also highlight women's presumed dependence on their husbands, reflecting symbolic and gender forms of violence in society more generally.

Article 155 of the Guatemalan Civil Code addresses common causes for obtaining a separation or a divorce and differentiates between women and men in several ways. For example, if a woman gives birth to a child that was conceived before the marriage, but the man did not know about the pregnancy before marrying, this constitutes grounds for divorce or separation. The law does not stipulate a parallel condition for the men. This law very much reflects the commonly held belief that women will want to marry even if it means tricking or coercing a man into doing so. The legal code thus conceptualizes women as likely to coerce men into marriage, but does not do the same for men, even when it can be easily argued that often men coerce or trick women into marrying. This happens with "robadas", that is, when men "steal" women and coax them into unions that women may sometimes agree to, but not always completely voluntarily [26]. Robadas are a common practice to initiate a union in Guatemala that affects all women, but especially the poor. ${ }^{6}$

The above law dovetails with laws that govern the age at marriage in Guatemala. Until 2015, Guatemalan law stipulated that boys could legally marry at 16, while the age limit was 14 for girls (this age was raised in 2015 to 18 years for both). Today, by law, a judge can make an exception, permitting a marriage under 18 years old, but no younger than 16. Early marriages overwhelmingly disadvantage girls, especially when they marry men who are much older than they are. According to official records, each year in Guatemala, there are approximately 4000 marriages of girls between 15 and 19 years of age and 73,000 pregnancies for girls between 10 and 19 years old, of which 4000 happen to girls between 10 and 14 years of age. In 2013, there were 1015 marriages of girls under 14 years old (a figure that does not include the more frequent free unions/cohabitation that can begin with a "robada"); between 2009 (when the Law Against Sexual Violence, Exploitation and Human Trafficking ${ }^{7}$ was approved) and 2012, there were 80,151 marriages of girls under 18 years of age. The UNICEF representative in Guatemala indicated that the change in the law that raises the age at marriage to 18 years could lead to a decrease in the number of early marriages. Consent in such unions is seriously questionable since the girls tend to be much younger. These marriages may easily be classified as forced, especially when coercion or bribery of the judges is involved on the part of the men, an irony, since Article 155 of the civil code implies that women would be more likely to engage in coercion or trickery to get a man to marry them..$^{8}$ Early age marriages are particularly detrimental for girls both in the short and long term. They interrupt the girls' normal development and put their health at risk due to the higher risks of early pregnancies, and in the long run, girls who marry early stop going to school. As such, these unions epitomize the various forms of violence that are normalized in women's lives.

Guatemalan law is consistent in its gendered differentiated treatment of women and men in divorce, as well as marriage. Article 162 observes that, from the moment a divorce petition is filed, the women and children will become protected by law to ensure their security and assets. The law establishes that child care is everyone's responsibility, and as such, it assumes the character of a public charge because constitutionally, it is the state's obligation to protect children. However, it creates a specific hierarchy of relatives for the legal guardianship of children if the parents are unable to care for them, which gives first preference to the paternal grandfather, then to the maternal

6 The practice of "stealing" women (or "robadas") [2,26] has taken different forms in Guatemala, but has not gone away with "modern" customs that have given more freedom to women and a say in their unions, as some experts have argued. Robadas have taken a different form within a generalized context of violence in which young women are forced into unions with gang members who threaten them or their families with death if they do not acquiesce to the union. In some instances, the results have been fatal, as in the case of a 16 year old girl who was killed on 20 April 2016 because she refused to accept being the girlfriend of a gang member.

7 Ley Contra la Violencia Sexual, Explotación y Trata de Personas.

8 This is exemplified by the case of a girl in the Petén region who was married at age 11 to a 34 year old man who lied about his age and then bribed the judge with Q.500 (\$65) to allow the marriage to take place [27]. 
grandfather, followed by the paternal grandmother and then the maternal grandmother, after whom follow siblings undifferentiated by sex or lineage. For the children from formalized unions (legal marriages), the paternal lineage is given preference; for children born to consensual unions, the maternal lineage is privileged. ${ }^{9}$ The law also creates exemptions for legal guardianship to individuals over 60 years of age, those who already have legal guardianship of someone else, those who have legal responsibility of three or more children, those with limited resources, those who must be outside of the country for one year or longer, those who suffer an illness that impedes their regular functioning and women. Thus, without physical injury and under the veil of formality and legal protection, the law perpetuates structures that harm and devalue women in multiple and profound ways.

\subsection{Alimony Law}

In cases of alimony, Article 169 establishes that women who are not at fault (for the divorce) will have the right to alimony while they observe "good conduct" and remain unmarried. The expectation of honorable conduct is rooted in the symbolic violence of extreme social control of women's bodies. Men who are not at fault in a divorce will enjoy the same rights to alimony, but only when they are unable to work to earn a living and remain unmarried. Creating expectations of "good behavior" for divorced women in order to "deserve" alimony payment places women at a serious disadvantage for several reasons, not the least of which is the continued control and surveillance that they are subjected to on the part of their ex-husbands (which often is the bases for violence that can end in feminicide). At the same time, divorced men are not subjected to the same expectation of "good conduct". However, these men are expected to fulfill the socially-expected role of being financially independent and are only able to obtain alimony if unable to work for a living.

\subsection{Property Law}

Between 1980 and 1990, property laws in Guatemala were rewritten and granted more formal equality to women (see also [28]). However, reflecting broader social forces, the legal code contains contradictions about women's entitlement to property. In practice, women are disadvantaged regarding property because inequalities permeate the legal system by articulating expected roles of women and men (that are made explicit in marriage laws). For example, the Civil Code notes that property is divided in half in marriage [29]. However, elsewhere it notes that everyone is entitled to the property for which they pay $[28,30]$. Therefore, if the man is the one who works and pays for property, then he would be entitled to the property.

Recall that elsewhere in the Civil Code, it is specified that men are obligated to provide economic support for the family and, logically, would be paying for property. In the case of rural agricultural land, there are no restrictions on women owning agricultural land, but land titles can only be held by one person [30]. Even though the majority of women in Guatemala live in rural areas, only a small percentage of women hold titles to agricultural land [28]. Thus, property ownership laws presuppose social practices that exist in a context of profound gender inequality and reinforce discrimination by limiting ownership in practice to the men who can pay for it. This is how multiple forms of violence, in their non-physical manifestations, shape the legal structures that guide this aspect of marital unions. Thus, property rights increasingly are recognized as a form of gender violence because they parallel the injuries that other forms of violence inflict [28].

This gender-discriminatory legal context, embedded within the broader social context of multisided violence, also contributes to sustain significant levels of impunity for violence against women (Figure 4 shows how the socio-legal context in Guatemala contributes to the normalization of

9 Interestingly, when interviewed in the United States, Guatemalan immigrant women who have left their children in the care of relatives back home overwhelmingly prefer to leave them with their own mothers, in practice giving preference to the maternal lineage regardless of the type of union. 
violence in general, as well as violence against women, also resulting in impunity for violence against women and re-instantiating this discriminatory context).

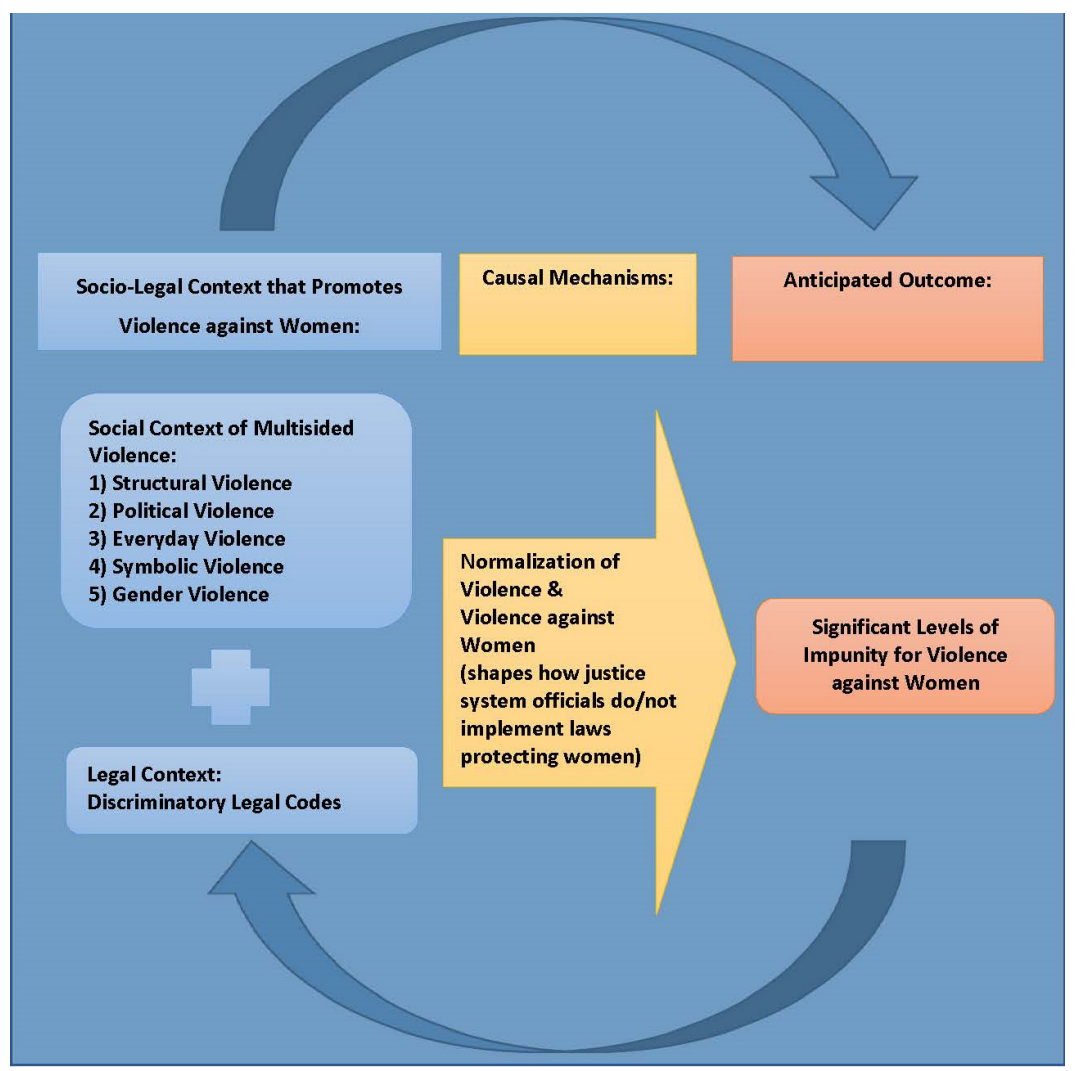

Figure 4. Social-legal context that results in impunity for violence against women.

Below, we describe the process of creating laws aimed at protecting women from violence, as well as the obstacles to their implementation, within a hostile socio-legal environment where the multiple forms of violence in women's lives co-exist. It will become obvious that laws passed to protect women will be ineffective and even impractical when adjacent laws continue to be discriminatory toward women, and a general context of deeply unequal conditions for women continues unaltered.

\section{The Contested Passage of VAW Laws in Guatemala}

Women's movement advocates in Guatemala pressured for years for the creation of specific VAW laws and laws to address feminicide [31]. At the regional level, international organizations worked in cooperation with grassroots advocates to provide technical assistance and pressure the government to formulate specialized laws [32]. These laws were considered necessary to confront alarming levels of violence against women and widespread discrimination and impunity. There was resistance within the Guatemalan male-dominated political arena to their adoption and subsequent resistance to their implementation. These new VAW laws are embedded in the context of the Civil Code, but also the discriminatory 1973 Penal Code. We will briefly compare these laws to the Penal Code below with a more detailed discussion of the Civil Code in the upcoming section.

Women's rights groups mobilized to have the Guatemalan Congress ratify the Inter-American Convention on the Prevention, Punishment and Eradication of Violence against Women, "Convention of Belém do Pará", which they did in 1995. These same women's groups initiated the enactment of the 1996 "Intrafamilial Violence Law", the Law to Prevent, Punish and Eradicate Intrafamilial Violence (Ley Para Prevenir, Sancionar y Erradicar la Violencia Intrafamilial). It was designed to protect battered women [33]. Hilda Morales Trujillo, a Guatemalan lawyer and internationally-recognized 
women's rights advocate, describes some advances and shortcomings of the Intrafamilial Violence Law. She says, it "defines intra-family violence as a human rights violation and recognizes domestic violence as a social problem. It also outlines measures available to courts in order to protect victims of domestic violence, yet it explicitly limits these protective measures stating they cannot exceed six months" ([33], p. 7). While these provisions aimed to harmonize this domestic law with Belem do Pará, there are several areas that fell short of international standards. One such lacuna is that the aim of the law was to address intrafamily violence, instead of violence against women. As such, it upheld the hierarchy of the family already embedded in the law, rather than explicitly recognizing the subordination and vulnerability of women within the family.

There was political resistance to the creation of the Intrafamilial Violence Law that limited its intended scope and content. According to Morales ([33], pp. 7-8), the "Guatemalan Congress only approved 14 out of 40 articles designed to change Guatemalan law to enhance protection for victims of domestic violence." One problem is that, according to Morales ([33], pp. 7-8), "even if it is properly applied and enforced, the most it results in is a husband being removed from the home for a limited period of time", and the probability that "he will return even angrier due to a report having been made...[The] law does not have an explicit enforcement or punishment provision, rendering it only marginally useful...Even if a woman were to succeed [in obtaining a protective order], the most she could accomplish would be to have the husband removed from the home for a short amount of time, though it is possible for a woman to ask of an extension beyond six months." Although the law does provide some redress for women, this limited legal framework does not allow for substantial protection in a context where structural, symbolic, gender and gendered forms of violence shape women's lives and the same forms of violence inform the cognitive frames of the individuals who can legally protect them.

In 2008, Guatemala enacted the "Femicide Law", the Law against Femicide and Other Forms of Violence against Women (Ley Contra el Femicidio y Otras Formas de Violencia Contra la Mujer). The "Trafficking Law", that is, the Law against Sexual Violence, Sexual Exploitation and Human Trafficking (Ley de Violencia Sexual, Explotación y Trata de Personas), was approved in 2009. The 2008 Femicide Law and 2009 Trafficking Law classify special crimes committed only against women and note that "violence against women is committed in a context of unequal power relationships between men and women, and that these women are being killed for reasons of gender within circumstances that only they suffer" ([33], p. 13). The Femicide Law was a significant symbolic victory for women's rights in calling attention to alarming rates of violence against women and feminicide in Guatemala.

The logic of the Femicide and Trafficking laws undermine that of the 1973 Penal Code, which defined sex crimes as violating the modesty of an "honest woman", rather than her physical integrity [34]. The notions of women's sexual modesty and honor in the Penal Code have historically been used to legitimize sexual violence against non-conforming women. These newer laws focus instead on holding perpetrators accountable for the act of violence rather than the victim's character [34]. Several articles of these new laws were used to revise the 1973 Penal Code, such as Article 26 of the Trafficking Law. In removing "the word pudor [modesty] and replacing it with indemnidad [indemnity] the law replaces a passive notion of a woman's honor's being protected [in the 1973 Penal Code] with a more active notion of her exercising her rights to sexuality free of coercion or violence [in the Trafficking Law]" ([34], p. 137). Noteworthy, Guatemala did not previously lack laws criminalizing the killings of women. However, it lacked the political will to enforce them in a context where women's suffering is not only part of the way things are, but it is often even expected [2].

There was fervent political resistance mostly by male Congressmen to the creation of the 2008 Femicide Law. At one point, these men threatened to leave Congress to prevent a quorum so that a vote could not be held ([33], p. 12). Morales observes that there was similar resistance to the creation of the 2009 Trafficking Law. Morales [33] notes that she met with some male and female prosecutors shortly after the Femicide Law was enacted and reports that: 
Their reaction to it was very negative, and they made remarks which demonstrated the deeply-held beliefs that women are responsible for the harm that is brought upon them, that new laws are not necessary, and that if women behaved themselves, they would not be battered, raped or killed. Some of them [prosecutors] held the prejudice that women are killed for belonging to "gangs" or for being involved in organized crime, or because once they were "granted" greater freedoms, they had become "licentious" and as a result their lives ended violently. Accordingly, although many women's rights organizations see the passage of the laws as important steps, at this point their provisions are largely symbolic, since they have yet to be implemented in any significant manner ([33], p. 13).

Since the will of prosecutors and judges is necessary to implement these laws, a persistent lack of implementation is not surprising in a context where prosecutors and judges view violence against women as normal, hold discriminatory attitudes against women and have the discretion to circumvent their application. A study conducted in Guatemala provides an example. Sixteen professionals who handle cases of domestic violence in the public and private sectors-physicians, nurses, policemen, lawyers, gynecologists, a journalist and a social worker-were asked about their views of relations between women and men. Overwhelmingly, the professionals agreed that "women must obey the men". When they were asked under what conditions it is acceptable for a man to assault a woman, five of them said that aggression is justified if there is jealousy, alcoholism or infidelity on the part of the woman. When they were asked if violence against women affected society in general, they responded negatively, indicating that these are isolated cases that do not have much wider effect [22]. This subset of professionals should in principle understand the broader causes and impacts of violence against women, e.g., that it is never justified, and that women should not be obliged to be obedient. Therefore, their views exemplify how the multisided violence of the social context reinforces women's subordination through shaping the cognitive frameworks of those in charge of interpreting and implementing VAW laws.

While the examples above demonstrate how the social context has posed obstacles to the passage and implementation of VAW laws, the discriminatory legal context in which these laws are embedded is often leveraged to reinforce women's subordination. In the upcoming section, we describe how justice system officials privilege various discriminatory aspects of the broader legal code in ways that undermine the intended application of VAW laws.

\section{Socio-Legal Context: Multisided Violence and Lack of Implementation in Guatemala}

In Guatemala, the justice system itself often poses obstacles to achieving justice [3]. In this milieu, as can be expected, the normalization of violence against women has impeded the implementation of laws designed to protect them. Laws will likely be ineffective and vacuous when they are passed without fundamental alterations to how women are treated, how gender inequality is normalized and how men's authority is upheld. In Guatemala, the Intrafamilial Violence Law, Femicide Law and Trafficking Law have persistent problems with their application by police, prosecutors and/or judges. In this section, we focus on the Intrafamilial and Femicide laws and identify several obstacles to implementation: (1) persistent victim blaming in a social context that impacts the interpretations of justice system officers; (2) utilizing adjacent laws and principles in the civil code, which already disfavor women, in a way that evades implementation; and (3) privileging competing discriminatory legal norms in the civil code that persist in family, marriage, divorce, alimony and property laws.

We provide evidence of these problems through the sworn testimony of two Guatemalan lawyers, Hilda Morales Trujillo and Elisa Portillo Nájera, who have decades of experience and expertise on violence against women and justice system failures in Guatemala $[1,33]$. Other sources provide analysis and reveal that these problems exist more broadly $[10,17,24,35]$. However, the testimonies enable a more in-depth analysis and provide specific examples of how these general patterns operate on the ground through the voices of Guatemalans intimately involved with the creation and implementation of the VAW laws. 


\subsection{Claiming Lack of Awareness of the Laws}

Justice system officials claim lack of awareness, or perhaps willful ignorance, of VAW laws to justify the lack of their application; underscoring the symbolic violence embedded in societal attitudes toward the violence women endure in the context of marital relations and the devaluation of women's lives more generally. Hilda Morales Trujillo, the Guatemalan lawyer and women's rights advocate mentioned earlier, provides an example of how this presumed lack of awareness emerges as a reason for the failure to implement the Intrafamilial Violence Law:

“...Guatemalan police, prosecutors and judges are generally unaware of the provisions of the 1996 [Intrafamilial Violence] Law. In some places, there are no judges or police nearby, and the mayor, who is the closest authority, does not know the law and lacks the legal training to apply it." ([33], p. 7).

For the 2008 Law Against Femicide and Other Forms of Violence Against Women, prosecutors and judges often claim that they do not understand its provisions and that it is very complicated, a position that disregards the value of women's lives and stands in stark contrast to how instances of "common crime", especially when gang members are involved, are dealt with. Thus, in the case of the 2009 Law Against Sexual Violence, Exploitation and Human Trafficking, justice officials argue that they are confused about applying one law over another.

The writing of the law itself, which we argue reflects society's attitudes that normalize violence in the lives of women, leaves room for confusion and for individual officials' interpretations that do not always match the law's intention. The 2008 Femicide Law delineates new crimes, such as "femicide", "psychological violence" and "economic violence". Elisa Portillo Nájera is a Guatemalan lawyer and a state functionary working to improve the implementation of VAW laws. She describes the seeming confusion over these laws, as well as blocked attempts to address it.

While the law attempts to define these new crimes, the definitions are unclear and, in some cases, confusing. For example, "femicide" is defined as the violent death of a woman that occurs in relationships of unequal power between men and women. The law sets forth circumstances under which a death would be considered a femicide, including where the killing was for reasons of "misogyny". Guidance, however, as to how to determine the existence of misogyny is not present in the law, leading to ambiguity and confusion, and leaving government officials free to apply their own understanding ([1], p. 12).

Some attempts have been made to remedy the apparently confusing language in the law as women's groups and some government agencies drafted a new protocol with guidance for their application. In 2010, the Supreme Court agreed that the protocol was necessary to make the Femicide Law effective, but "refused to make the protocol binding guidance for judges, preferring to simply recommend that judges follow it" ([1], p. 12). Again, the lack of political will to make this protocol binding, a position reflecting an indifferent attitude about crimes against women, serves as a continuing obstacle to its appropriate implementation.

Another problem embedded in the technical application of the law is lack of proof: if evidence is not collected at the scene of the crime, it is very difficult to reconstruct the facts later [33]. Morales notes that "there is so much sluggishness and indifference in the desire to understand and apply these laws that impunity continues to prevail in the vast majority of cases" ([33], p. 12). However, even when victims' families volunteer resources to help police collect evidence, the police are sluggish and inefficient in these efforts [3], demonstrating a general disregard for the violence women endure and a persistent devaluation of women's suffering and their lives more generally. In a context where violence against women is not seen as extraordinary, it is also "normal" to dismiss the importance of basic investigatory procedures, such as collecting and preserving evidence. In other cases, justice system institutions fail to follow legal directives to provide women with protection and justice. For example, the Public Prosecutor's office will often fail to carry through with investigations if women decide to drop charges, further contributing to impunity [34]. 


\subsection{Persistent Victim Blaming}

Victim blaming is widespread in the Guatemalan legal system, exposing the symbolic violence that permeates institutions and bureaucracies charged with the protection of women. Therefore, even when police or judges are aware of the laws meant to protect women from violence, they often interpret these laws through discriminatory cognitive frameworks and apply them in ways that reinforce women's subordination. Portillo describes victim blaming that is rooted in a lack of understanding the context of abused women's lives and also in normative frameworks that place the culpability for the abuse on victims rather than perpetrators, exemplifying the symbolic violence that shapes the cognitive frameworks of these officials:

"Women who do turn to law enforcement personnel and judicial officials do not receive protection because these patriarchal norms are so deeply entrenched that the officials act in a biased way towards women. When a woman tries to report the abuse to the police, they often treat her as if she were causing the problem. Law enforcement and judicial officials often blame women for their partners" "misbehavior". In one instance, a judge at a training I held asked me if I would please inform the women not to dress too provocatively and cause men to commit crimes. In other instances, women have reported to me that problems can be fixed if the woman complies with norms specified by society, such as preparing a man's favorite meal...Furthermore, these officials are often indifferent to or ignorant about the cycle of domestic violence, whereby women are abused over and over or even killed by their partners." ([1], pp. 4-5).

In a socio-legal context that normalizes violence and women's suffering to the point where victims are blamed for the violence committed against them, justice system officials often refuse to grant basic protections to women. This is evident in the limited granting and enforcement of protection orders, which is a mechanism of protection written into the Intrafamilial Violence Law. As Morales notes,

"I know only of a very few cases in which the woman has succeeded in having the husband removed, even for a short period of time. In addition, the orders in and of themselves are not sufficient to guarantee women's safety, as exemplified by the 2007 murder of Rosa María Morales, which occurred when the husband arrived at the victim's home, climbed up a ladder he placed on the outside wall, entered the bedroom of the home and killed her." ([33], p. 8)

Portillo notes further problems with the lack of enforcement of protection orders and even justice system officials who claim that implementing them is even unconstitutional:

“Even when judges do decide to order protective measures, they do not order measures that will sufficiently protect women. Judges have the power under the law to order an array of measures designed to protect women, and to provide them and their children with financial support. Some judges may order that the aggressor stay away from the victim and her children, or that the man leave the home, but they almost never order measures providing support for her and her children. In some cases, where judges value property rights over the safety of women, judges have refused to order men removed from their homes because they consider it unconstitutional. This is clearly an ineffective application of the law." ([1], p. 8).

In these examples, the intersection of the deeply unequal social context with discriminatory legal codes that normalize violence against women becomes evident. While family laws specify that women should take care of the household, justice system officials are observed drawing on this legal framework to justify violence in instances where they perceive women are ignoring their duties to cook a good meal or even clothe themselves conservatively. In addition, justice system officials have the discretion to apply the few legal protections offered in the law, such as issuing and implementing 
protection orders. Thus, the socio-legal context is used to reinforce women's subordination despite the existence of laws meant to protect them from violence.

\subsection{Utilizing Adjacent Laws and Principles to Undermine VAW Laws}

Justice system officials have the discretion to (and often do) prioritize other "adjacent" laws and principles in the Civil and other codes that compete with the application of VAW laws. The assumption of equality under the law leads to contradictory ends when officials assume that equality exists, rather than recognizing the widespread gender inequality that VAW laws are meant to remedy. The context of multisided violence in Guatemala we call attention to creates the conditions for this indifference and reluctance to apply the Intrafamilial Violence Law. For these officials, as for the people in women's lives and for the women themselves, violence in their lives is part of life. Using the "equality" framework to justify the officials' refusal to apply this law in Guatemala exemplifies how the symbolic violence that depreciates women seeps through to shape the minds of justice system bureaucrats in a way that distorts their interpretation of this law. As Morales notes, “...even when judges are aware of the 1996 [Intrafamilial Violence] Law, they are reluctant to apply it, claiming that it is unconstitutional and goes against the concept of equality, because it allegedly gives women more rights than men..." ([33], p. 7). When confronted with applying VAW laws, police, prosecutors, and judges often leverage other adjacent laws, including the family, divorce, marriage, alimony and property laws, in order to reinforce women's subordination.

\subsection{Family, Divorce and Marriage Laws}

Recall that the broader multisided violence and discriminatory legal context institutionalize the subordination of women within the context of the family and marriage. For example, gendered roles, formalized in law, specify that women are in charge of the household, while the only household responsibilities specified for men are to be the providers. Consequently, the subordination of women within the context of marriage is often reinforced when women report violence within it:

“...women have reported to me that policemen have suggested that problems can be fixed if the woman complies with norms specified by society, such as preparing a man's favorite meal. Because the police, prosecutors, and judges believe that men have the right to use violence against their partners to control them, they do not take cases of violence against women seriously." ([1], p. 5).

\subsection{Alimony Laws}

Women experience the brunt of structural, gender and symbolic violence when they live in situations of economic dependence on abusive partners. In cases where women want to pursue a divorce, the legal system itself poses several obstacles for doing so. In accord with property laws, "women usually do not gain title to property when they marry, so if they divorce they are not entitled to any of the property used by the couple" ([1], p. 12). In addition, alimony laws pose additional obstacles to divorce, again, particularly when women are economically dependent on men because there are simply fewer employment opportunities for women that can guarantee a living wage. As Portillo notes,

"A man can effectively prevent his wife from obtaining a divorce if he claims that he cannot provide the necessary financial support for the children. In such cases, judges often indefinitely suspend the divorce proceedings. Judges justify this by a mistaken reliance upon the principle that the rights of the child must be protected-and if support cannot be provided subsequent to divorce, then the divorce should not go forward." ([1], p. 12).

Instead of judges privileging women's safety or autonomy, the principles of family law (which favor the interests of the family as a unit) that reinforce women's role as caretakers of the children are upheld. At the same time, property laws deny women access to property, and alimony laws fail to require men to provide sufficient support for women after (rather than during) a marriage. 


\subsection{Property Laws}

Morales [33] argues that the patriarchal framework embedded in the legal system is one foundation for the legal situation that battered women face in Guatemala. She notes that, despite the fact that the Guatemalan Constitution guarantees equality among the sexes, judges often say they cannot apply the Intrafamilial Violence Law in Guatemala because it can violate property rights ([33], p. 10). Morales notes that "Judges will often say that if a man owns the house, he cannot be ordered removed" ([33], p. 10), a case that demonstrates how gender violence and power imbalances in the broader society seep through to shape the frames the judges use to weigh the case. Under Guatemalan law, only the official title holder is entitled to the property. Additionally, given that women are economically disadvantaged, they cannot afford the legal representation to initiate a lawsuit to claim their half of the property ([33], p. 10).

In addition, judges often refuse to apply the Intrafamilial Violence Law arguing that it is unconstitutional or that it disregards judicial process, particularly when it comes to privileging property laws over VAW laws. One example is that the law allows police to seize weapons used to threaten a woman, but judges will claim this is an inconsistency because individuals are allowed to have licensed weapons. The judges will therefore conclude that the Intrafamilial Violence Law is unconstitutional and refuse to use it to take action to protect women from additional abuse ([33], p. 11).

Secondly, judges argue that the Intrafamilial Violence Law disregards judicial process under which a person cannot be convicted if he or she has not been cited, heard and tried. Judges will claim that security methods (e.g., protection orders) are improper because they lack full judicial procedures ([33], p. 11). However, there are other precautionary measures that do not follow traditional judicial processes that judges readily accept in other cases, such as liens upon bank accounts imposed by debtors ([33], p. 11).

Thus, while refusals on the grounds of unconstitutionality or judicial process may appear rooted in the structure of the law or judicial attitudes about the Intrafamilial Violence Law itself, judges' attitudes toward women's role in society and the family unit, where gender and symbolic violence coalesce, certainly play just as strong a role in their refusal to apply the law. It appears that judges have no compunction about applying unjust property laws favoring men, but refuse to apply what they view as unjust laws protecting women. This should not come as a surprise in a context that normalizes women's subordination in multiple spheres of life.

In addition to these specific examples from Guatemala, there is a broader regional legal trend that enables children to immediately inherit part of the estate of a male spouse, rather than have it go first to the widow [36]. This puts widowed women in a precariously dependent position upon their children. The situation is even more precarious for women in common-law marriages (uniones de hecho), because the onus is on the widow to demonstrate that the property was acquired during the union [36]. Since common-law marriage is widespread in Guatemala, this makes widows more vulnerable to conflicts that can escalate to threats and even violence from their children or their spouses with legal claims to spousal property.

\section{Discussion and Conclusions}

We argue in this article that a context of multisided violence seeps through to shape the discriminatory legal code in Guatemala, and together, these forces converge to normalize and formalize discriminatory treatment of women, lack of enforcement of laws meant to protect women and a general depreciation of their lives. The normalization of violence in women's lives (and its formalization in adjacent laws) shapes the cognitive frames of justice system officials and, as such, poses obstacles to the implementation of specific laws meant to address violence against women. Police, prosecutors and judges justify the lack of enforcement through drawing on familiar social roles to justify keeping women constrained to their "appropriate" roles in the household, as well as privileging formal "adjacent" laws that challenge VAW laws and institutionalize women's subordination. 
While much of the existing literature focuses on individual-level acts of violence against women, we instead focus on the broader social and legal context to demonstrate how they converge to normalize and justify ongoing violence against women and to shape the interpretation and (lack of) implementation to protect women. In principle, the law should be an arena where the less powerful are put on equal footing with the more powerful, but in the context of Guatemala, it often becomes an arena where women's relative lack of power is reinforced and its effects amplified when they seek help. While discriminatory socio-legal practices are deeply entrenched in the multiple inequalities that permeate everyday life in Guatemala, there are attempts to change them, such as the Intrafamilial Violence Law and the Femicide Law, a legal instrument that makes some progress in remedying these patterns. Even longstanding discrimination can change, and here, we make some recommendations to make VAW laws more effective by concomitantly attending to the broader socio-legal context.

Transnational feminist networks mobilized for the creation of new laws to protect women from violence throughout Latin America [32], but similar mobilization has not emerged to pressure for or to provide consultation for modifying adjacent legal codes that are obstacles to implementing these new laws. Such legal advocacy has been, and could be, effective in a context that is discriminatory, but still vulnerable to international pressure [37]. For instance, in response to a United Nations report and international pressure, the Guatemalan government raised the country's minimum age of marriage to 18 , though no changes have been made to stop the corruption of judges who still authorize under-age marriages of girls. In addition, grassroots campaigns (which are often internationally funded) have been launched to raise awareness of violence against women. Avon has funded campaigns throughout Latin America, including billboards posted throughout Guatemala City that say “Don't put make-up on it", in order to try to reduce the stigma of being a victim of domestic violence and increase reporting. Most international donors disproportionately focus on these kinds of projects, with short-term goals and measurable results [37]. Few, if any, of these campaigns address gender inequality or other structural factors, such as poverty and across-the-board gender inequalities that constitute the root cause of women's vulnerability to violence. International donors would need to redirect funding to these longer term goals that grassroots advocates could frame in ways that are persuasive and effective for local citizens.

The social context of Guatemala includes multiple forms of violence that exist in tandem and ultimately reinforce one another. Structural, symbolic, everyday, gender and the long arm of political violence coalesce to shape the lives of women in multiple ways. However, social positions dictated by gender, ethnicity and social class modify the experiences of violence for Guatemalan women and their interactions with institutions and state agencies. Addressing these other types of violence, which are more deeply embedded and even seen as "part of life", would help denaturalize violence in general, make violence against women less ordinary and provide women with resources so that they can have real opportunities for dignified lives. For example, steps could be taken to address structural violence by reducing widespread poverty and inequality; tackle impunity for political violence by increasing accountability for political crimes during the civil war, especially those committed against women; disrupt everyday violence by improving citizen security and address corruption; undermine symbolic violence by naming instances of violence against women as such, thus making them visible and exceptional; and undermine gender violence directly through social and legal advocacy.

The creation of new laws is an important part of a broader advocacy strategy to empower women in ways that makes them less vulnerable to violence in the first place. These are necessary, but not sufficient. Significantly more work is needed to remedy broader socio-legal structures that operate to reinforce, rather than undermine, women's subordination.

Acknowledgments: The authors are deeply grateful to Andrea Gómez Cervantes, Barbara Drysdale, and Daniel Drysdale for editorial assistance, as well as to the reviewers for their very helpful comments.

Author Contributions: Authors are listed in alphabetical order; they contributed equally to this article.

Conflicts of Interest: The authors declare no conflict of interest. 


\section{References}

1. Portillo Nájera, Elisa. “Declaration of Guatemala Expert Elisa Portillo Nájera.” 2012. Available online by request through the Center for Gender \& Refugee Studies: http:/ /cgrs.uchastings.edu/assistance/request (accessed on 20 September 2013).

2. Menjívar, Cecilia. Enduring Violence: Ladina Women's Lives in Guatemala. Berkeley: University of California Press, 2011.

3. Walsh, Shannon Drysdale, and Cecilia Menjívar. “'What Guarantees Do We Have?' Legal Tolls and Persistent Impunity for Feminicide in Guatemala." Latin American Politics and Society, 2016, forthcoming.

4. Menjívar, Cecilia, and Olivia Salcido. "Immigrant Women and Domestic Violence: Common Experiences in Different Countries." Gender \& Society 16 (2002): 898-920. [CrossRef]

5. Godoy-Paiz, Paula. "Women in Guatemala's Metropolitan Area: Violence, Law, and Social Justice." Studies in Social Justice 2 (2008): 27-47.

6. UN. "Report of the Special Rapporteur on Violence against Women, Its Causes and Consequences, Rashida Manjoo. Addendum: Follow-Up Mission to El Salvador. Human Rights Council. Seventeenth Session. Report number A/HRC/17/26/Add.2." 1 February 2011. Available online: http://www.ohchr.org/ Documents/Issues/Women/A.HRC.20.16_En.pdf (accessed on 1 July 2016).

7. Fox, Edward. "How the Drug Trade Fuels Femicide in Central America." 12 July 2012. Available online: http: //www.insightcrime.org/news-analysis/how-the-drug-trade-fuels-femicide-in-central-america (accessed on 15 July 2014).

8. Crenshaw, Kimberle. "Mapping the Margins: Intersectionality, Identity Politics, and Violence against Women of Color." Stanford Law Review 43 (1991): 1241-99. [CrossRef]

9. Levenson, Deborah T. Adiós Niño: The Gangs of Guatemala City and the Politics of Death. Durham and London: Duke University Press, 2013.

10. Laynez, Gloria Esperanza, and Juana Sotz. La Institucionalidad de DEMI y su Impacto en la Protección y Defensa de los Derechos de las Mujeres Indígenas. Ciudad de Guatemala: Defensoria de la Mujer Indígena, 2013.

11. Torres-Rivas, Edelberto. "Sobre el terror y la violencia política en América Latina." In Violencia en una Sociedad en Transición. San Salvador: Programa de Naciones Unidas para el Desarrollo (PNUD), 1998, pp. 46-59.

12. Farmer, Paul. Pathologies of Power: Health, Human Rights, and the New War on the Poor. Berkeley: University of California Press, 2003.

13. Bourgois, Philippe. "The Continuum of Violence in War and Peace: Post-Cold War Lessons from El Salvador." In Violence in War and Peace: An Anthology. Edited by Nancy Scheper-Hughes and Philippe Bourgois. Malden: Blackwell, 2004, pp. 425-34.

14. Ball, Patrick, Paul Kobrak, and Herbert F. Spirer. State Violence in Guatemala, 1960-1996: A Quantitative Reflection. Washington: International Center for Human Rights Research, American Association for the Advancement of Science, 1999.

15. Martín-Baró, Ignacio. "Violence in Central America: A Social Psychological Perspective." In Towards a Society That Serves Its People: The Intellectual Contributions of El Salvador's Murdered Jesuits. Edited by John Hassett and Hugh Lacey. Translated by Anne Wallace. Washington: Georgetown University Press, 1991, pp. $333-46$.

16. Sanford, Victoria. Guatemala: Del Genocidio al Feminicidio. Guatemala: F\&G Editores, 2008.

17. Ertürk, Yakin. "Integration of the Human Rights of Women and the Gender Perspective: Violence against Women. Report of the Special Rapporteur on Violence against Women Its Causes and Consequences. Mission to Guatemala. Report number E/CN.4/2005/75/Add.3." 10 February 2005. Available online: http: / /www.ohchr.org/EN/Issues/Women/SRWomen/Pages/AnnualReports.aspx (accessed on 6 July 2016).

18. Ruiz-Navarro, Catalina. "Guatemala Sexual Slavery Verdict Shows Women's Bodies Are Not Battlefields." The Guardian, 29 February 2016. Available online: http://www.theguardian.com/global-development/ 2016/feb/29/guatemala-sexual-slavery-verdict-womens-bodies-battlefields-sepur-zarco (accessed on 29 February 2016).

19. Bourdieu, Pierre. "Gender and Symbolic Violence." In Violence in War and Peace: An Anthology. Edited by Nancy Sheper-Hughes and Philippe Bourgois. Malden: Blackwell, 2004, pp. 339-42.

20. Auyero, Javier. "In Harm's Way at the Urban Margins." Ethnography 13 (2012): 531-57. [CrossRef]

21. Hammar, Lawrence. "Caught between Structure and Agency: The Gender of Violence and Prostitution in Papua New Guinea." Transforming Anthropology 8 (1999): 77-96. [CrossRef] 
22. Programa Mujer, Salud y Desarrollo. Estudio Exploratorio: Violencia Intrafamiliar Hacia la Mujer en Guatemala. Guatemala: Ministerio de Salud Pública y Asistencia Social, Programa Mujer, Salud y Desarrollo, 1993.

23. UNDP. “Gender Inequality Index." Available online: https://data.undp.org/dataset/Table-4-GenderInequality-Index/pq34-nwq7 (accessed on 15 December 2012).

24. Escoto, Jorge, Ana Leticia Aguilar, Julieta Hernández, and Manfredo Marroquín. El acceso de la mujer a la tierra en Guatemala. San José: Fundación Arias para la Paz y el Progreso Humano, 1993.

25. “Civil Code of Guatemala. Decree-Law Number 206." 2010. Available online: http:/ /www.monografias. com/trabajos95/codigo-civil-guatemala/codigo-civil-guatemala.shtml (accessed on 29 May 2016).

26. Menjívar, Cecilia. "Normalizing Suffering, Robadas, and Marital Unions among Ladinas in Eastern Guatemala." In Marital Rape: Consent, Marriage and Social Change in Global Context. Edited by Kersti Yllö and M. Gabriela Torres. Oxford: Oxford University Press, 2016, pp. 75-85.

27. Sinclair, Stephanie. "Child, Bride, Mother: Guatemala." New York Times Sunday Review, 2015. Available online: http:/ / nyti.ms /295IbJO (accessed on 29 May 2016).

28. Deere, Carmen Diana, Susana Lastarria-Cornhiel, and Patricia Costas. Tierra de Mujeres: Reflexiones Sobre El Acceso de Las Mujeres Rurales a La Tierra En América Latina. La Paz: Coalición Internacional para el Acceso a la Tierra, 2011.

29. Sigüenza, Gustavo. Código Civil Decreto-Número 106. Guatemala: Universidad Rafael Landívar, 2010.

30. Congreso de la Republica de Guatemala. Ley de Transformacion Agraria. Decreto Número 1551. 1962.

31. Walsh, Shannon Drysdale. "Engendering Justice: Constructing Institutions to Address Violence against Women." Studies in Social Justice 2 (2008): 48-66.

32. Friedman, Elisabeth Jay. "Re(gion)alizing Women's Human Rights in Latin America." Politics E Gender 5 (2009): 349-75. [CrossRef]

33. Morales Trujillo, Hilda. “Declaration of Guatemala Expert Hilda Morales Trujillo." 2009. Available online by request through the Center for Gender \& Refugee Studies: http:/ /cgrs.uchastings.edu/assistance/request (accessed on 20 September 2013).

34. England, Sarah. “Protecting a Woman's Honor or Protecting Her Sexual Freedom? Challenging the Guatemalan Patriarchal State through Reforms to Sexual Violence Legislation." Latin American Perspectives 41 (2014): 124-42. [CrossRef]

35. Musalo, Karen, and Blaine Bookey. “Crimes without Punishment: An Update on violence against Women and Impunity in Guatemala." Hastings Race and Poverty Law Journal 10 (2013): 265-92.

36. Deere, Carmen Diana, Jacqueline Contreras, and Jennifer Twyman. "A Study of Women's Property Rights in Ecuador." Latin American Perspectives 41 (2014): 143-65. [CrossRef]

37. Walsh, Shannon Drysdale. "Not Necessarily Solidarity: Dilemmas of Women's Transnational Advocacy Networks." International Feminist Journal of Politics 18 (2015): 1-22. [CrossRef] 